\section{Evaluation of Polyolefin-coated Urea for Potato Production on a Sandy Soil}

\author{
Francis Zvomuya ${ }^{1}$ and Carl J. Rosen ${ }^{2}$ \\ Department of Soil, Water, and Climate, University of Minnesota, 1991 Upper \\ Buford Circle, St. Paul, MN 55108
}

Additional index words. Solanum tuberosum, polyolefin-coated urea, controlled-release fertilizer, economic analysis

\begin{abstract}
Field studies were conducted on a Hubbard loamy sand (sandy, mixed, frigid Entic Hapludoll) during 1996 and 1997 at Becker, Minn., to evaluate the effect of a polyolefin-coated urea (POCU) fertilizer (Meister, Chisso Co., Japan) on yield and quality of irrigated 'Russet Burbank' potatoes (Solanum tuberosum L.). The POCU was a 3:1 mixture of 70-day and 50-day release formulations, respectively, based on historical soil temperatures at the site. The study compared five banded nitrogen $(N)$ rates $(110,155,200$, 245 , and $290 \mathrm{~kg} \cdot \mathrm{ha}^{-1} \mathrm{~N}$ ) as a split application of urea applied at emergence and hilling, vs. POCU applied at planting. All plants received an additional $30 \mathrm{~kg} \cdot \mathrm{ha}^{-1} \mathrm{~N}$ as monoammonium phosphate band-applied at planting. Yields were higher in 1996 because of cooler temperatures and poor tuber set in 1997. Total and marketable yields averaged, respec-

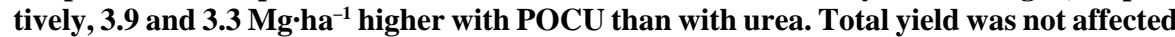
by rate of $\mathrm{N}$ application regardless of source, but marketable yield increased linearly with $\mathrm{N}$ rate. The yield of marketable tubers larger than $170 \mathrm{~g}$ increased linearly with $\mathrm{N}$ rate in both years. Gross return was $10 \%$ higher with POCU than with urea, but estimated net return showed a significant source $\times N$ rate interaction. The net return increased by $\$ 3.13$ per kg of urea-N applied, but there was no significant change across POCU application rates.
\end{abstract}

In the upper midwestern United States, the potato is often grown on glacial outwash soils that are generally infertile, with low waterholding capacity and rapid drainage. Nitrogen and water requirements of the crop are met through high rates of $\mathrm{N}$ fertilizer application and sprinkler irrigation. These factors, together with the shallow root system of potato plants and unpredictable rainfall, can lead to significant leaching of nitrate $\left(\mathrm{NO}_{3}^{-}\right)$to shallow groundwater.

Current practices to minimize $\mathrm{NO}_{3}^{-}$leaching in potato production involve split-application of soluble $\mathrm{N}$ fertilizers, with a small fraction of the total $\mathrm{N}$ requirement applied at or before planting. Subsequent applications are usually split at emergence and hilling, with later applications based on petiole analysis (Errebhi et al., 1998a, 1998b). However, because of the high $\mathrm{N}$ and water requirements of the potato and the use of highly soluble $\mathrm{N}$ fertilizers, controlling $\mathrm{NO}_{3}^{-}$leaching is difficult.

Another approach that merits further investigation is use of controlled release fertilizers (CRF). Previous studies with potatoes,

\footnotetext{
Received for publication 25 Apr. 2000. Accepted for publication 10 Aug. 2000. We thank Michael P. Russelle and Satish C. Gupta for their helpful comments on an earlier draft of the manuscript. This study was supported by Helena Chemical Co.(USA) and Chisso Co. (Japan). The cost of publishing this paper was defrayed in part by the payment of page charges. Under postal regulations, this paper therefore must be hereby marked advertisement solely to indicate this fact.

${ }^{1}$ Graduate Research Assistant

${ }^{2}$ Professor and Extension Soil Scientist. To whom reprint requests should be addressed (crosen@ soils.umn.edu).
}

however, have generally resulted in lower yields with CRF than with soluble $\mathrm{N}$ sources (Maynard and Lorenz, 1979; Waddell et al., 1999). Lorenz et al. (1972, 1974) reported lower yields of 'White Rose' potatoes with sulfur-coated urea (SCU) and ureaform than with ammonium sulfate. Cox and Addiscot (1976) reported similar results for 'Pentland Crown' potatoes; yields with SCU were lower than those obtained with calcium nitrate. For 'Russet Burbank' potatoes, Liegel and Walsh (1976) found that SCU was a better N source than urea only in cases where severe leaching occurred. In general, however, yields with urea were higher than with SCU under normal soil moisture conditions. Based on these studies, Maynard and Lorenz (1979) concluded that $\mathrm{N}$ release rates from conventional CRFs such as SCU or ureaform are too slow to meet the $\mathrm{N}$ demand of the potato plant early in the growing season. In addition, late season release of $\mathrm{N}$ from CRFs cannot substitute for retranslocation of high internal $\mathrm{N}$ concentrations from early season uptake. Under Minnesota conditions, Rosen et al. (1992, 1993) found that $\approx 70 \%$ to $80 \%$ of the $\mathrm{N}$ uptake by 'Russet Burbank' potatoes occurs between 20 and $60 \mathrm{~d}$ after emergence. Having $\mathrm{N}$ available for uptake during this period is therefore critical. If $\mathrm{N}$ is available too early in the season, it may be lost by leaching before uptake by the crop; if $\mathrm{N}$ is available too late it may not be used efficiently for tuber production. These studies suggest that some soluble $\mathrm{N}$ fertilizer may be needed along with a CRF at planting to meet early potato $\mathrm{N}$ needs.

Recently, several new controlled-release $\mathrm{N}$ fertilizer products have been developed (Trenkel, 1997). The new products are coated with polymers that allow $\mathrm{N}$ release to be synchronized better with crop $\mathrm{N}$ demands than when conventional CRFs are used. Release of $\mathrm{N}$ from polyolefin-coated urea (POCU) is primarily influenced by soil temperature (Gandeza et al., 1991). Since plant growth is also temperature-dependent, a more synchronous relationship between $\mathrm{N}$ demand and availability may be attained during the season. Use of such fertilizers may be an efficient means to maximize $\mathrm{N}$ use efficiency and minimize $\mathrm{NO}_{3}{ }^{-}$ losses. Results from recent studies demonstrated that polyolefin-coated (POC) CRF not only improved $\mathrm{N}$ use efficiency of corn (Shoji et al., 1991), but also decreased $\mathrm{NO}_{3}$ leaching (Alva, 1992; Wang and Alva, 1996). The influence of these newer CRFs on irrigated potato yield has not been documented. The objectives of this research were to: 1 ) determine the effects of POCU fertilizer on potato yield and quality; and 2) evaluate the economics of using POCU vs. soluble urea as the $\mathrm{N}$ source.

\section{Materials and Methods}

Field studies were conducted during 1996 and 1997 at the Univ. of Minnesota Sand Plain Research Farm in Becker, Minn., on a Hubbard loamy sand (sandy, mixed, frigid Entic Hapludoll). During each year prior to establishment of the experiment, rye (Secale cereale L.) was grown without fertilizer $\mathrm{N}$ in the experimental field to minimize the potential effects of residual profile $\mathrm{NO}_{3}{ }^{-} \mathrm{N}$ on crop response to $\mathrm{N}$ treatments. The experiment each year was conducted in a different field, but on soils with similar properties. Soil samples were collected from the surface $15 \mathrm{~cm}$ each spring for initial soil test analyses before treatment. Residual soil $\mathrm{NO}_{3}{ }^{-} \mathrm{N}$ was determined in composite samples taken to a depth of $60 \mathrm{~cm}$. After drying at $35^{\circ} \mathrm{C}$ and grinding to pass a 2-mm sieve, the soil samples were analyzed for $\mathrm{pH}$ (Thomas, 1996), organic matter content (Nelson and Sommers, 1996), extractable phosphorus (Bray P1) (Kuo, 1996), and exchangeable potassium (Knudsen et al., 1982). Nitrate-N in the samples was measured conductimetrically after extraction with $2 \mathrm{M}$ $\mathrm{KCl}$ (Carlson et al., 1990). Selected soil chemical properties in the $0-15-\mathrm{cm}$ depth prior to planting averaged: $\mathrm{pH}, 6.7$; organic matter, $2.1 \%$; Bray P1, $36 \mathrm{mg} \cdot \mathrm{kg}^{-1}$; and exchangeable $\mathrm{K}, 137 \mathrm{mg} \cdot \mathrm{kg}^{-1}$. Nitrate-N in the top $60 \mathrm{~cm}$ was $12 \mathrm{~kg} \cdot \mathrm{ha}^{-1}$ in 1996 and $20 \mathrm{~kg} \cdot \mathrm{ha}^{-1}$ in 1997.

The test cultivar was 'Russet Burbank', an indeterminate cultivar maturing in $\approx 120$ $130 \mathrm{~d}$, and the one most widely grown for potato processing in the upper Midwest. Cut "A" size seed potatoes were planted by hand the third week in April each year. Each plot received standard basic fertilization recommended for 'Russet Burbank' potatoes in the area (Rosen and Eliason, 1996). One week prior to planting each year, $225 \mathrm{~kg} \cdot \mathrm{ha}^{-1}$ potassium-magnesium sulfate and $225 \mathrm{~kg} \cdot \mathrm{ha}^{-1}$ potassium chloride were broadcast and incorporated. At planting, monoammonium phosphate and additional potassium fertilizer were banded $7.5 \mathrm{~cm}$ to the side and $5 \mathrm{~cm}$ below each seed 
piece to supply $30,55,166,20$, and $40 \mathrm{~kg} \cdot \mathrm{ha}^{-1}$ of $\mathrm{N}, \mathrm{P}, \mathrm{K}, \mathrm{Mg}$, and $\mathrm{S}$, respectively. The preweighed fertilizers were carefully applied at row opening using a precalibrated, tractordrawn applicator.

Two sources of $\mathrm{N}$ were evaluated at five rates of application. The sources were urea (46-0-0) and POCU (40-0-0), which is a CRF. The CRF was a 3:1 mixture, based on historical soil temperatures at the site, of 70-d$(75 \%)$ and $50-d-(25 \%)$ release POCU formulations. The formulations are so-named because, when immersed in water at $25^{\circ} \mathrm{C}$ according to the standard test procedure, they release $80 \%$ of their $\mathrm{N}$ in 70 and $50 \mathrm{~d}$, respectively (Shoji and Gandeza, 1992). Since the polyolefin coating material is thermoplastic, release rate and duration vary with soil temperature. The $\mathrm{N}$ rates were $110,155,200,245$, and $290 \mathrm{~kg} \cdot \mathrm{ha}^{-1}$, in addition to the $30 \mathrm{~kg} \cdot \mathrm{ha}^{-1} \mathrm{~N}$ applied at planting to all plots. All urea at each rate was added in two equal split applications at emergence (last week in May) and hilling (second week in June), according to conventional practice in the region. All POCU N was applied at planting along with the starter fertilizer. Both fertilizers at all rates were applied in a double band, as described above for the basic fertilization (Rosen andEliason, 1996). Weeds, pests, and diseases were controlled using standard practice (Hutchison, 1996). Irrigation water requirements to supplement rainfall were scheduled according to the checkbook method (Wright and Bergsrud, 1991) to maintain a soil moisture deficit of $25 \mathrm{~mm}$ or less during the vegetative growth stage and $14 \mathrm{~mm}$ or less during tuber bulking. Rainfall and air temperature data were collected from a weather station located near the experimental plots.

Treatments were laid out in a $2 \times 5$ factorial consisting of two sources of $\mathrm{N}$ and five rates of application in a randomized complete-block design with four replications. Each plot was 6 $\mathrm{m}$ in length and 4 rows wide, the middle two rows of which were harvest rows. Spacing was $25 \mathrm{~cm}$ in the row and $90 \mathrm{~cm}$ between rows.

Vines in the harvest rows were chopped 2 weeks before final tuber harvest to allow for sufficient time for tubers to set skin. Potato tubers were harvested the third week in September, using a one-row, tractor-drawn mechanical digger from the full length of the two harvest rows (minus the two border plants in each row). The tubers were size-graded and weighed for total and graded yield. Marketable yield was calculated by subtracting misshapen (cull) and undersized ( $<85 \mathrm{~g})$ tuber yields from the total yield. A 25-tuber sample was taken from each plot to determine hollow heart incidence and specific gravity. Hollow heart was assessed after cutting the sample tubers in half. Tubers with incipient (brown center) or fully developed hollow heart at least $1.25 \mathrm{~cm}$ in diameter were counted and the data were expressed as a percentage of all tubers assessed per plot. Specific gravity was measured using the hydrometer method (Snack Food Association, Alexandria, Va.).

Data were compared using analysis of variance (ANOVA) procedures, and $\mathrm{N}$ rate main effects and interactions were partitioned into linear and quadratic components. Statistical analyses were performed using SAS version 6.12 (SAS Institute, 1990). Combined analysis was performed across years for all parameters. Replicates and years were treated as random effects in the analysis. Main effects and interactions were considered significant if $P \leq 0.10$.

\section{Results and Discussion}

Weather. The 1996 season was slightly cooler in April than the long-term average, but the remainder of the growing season was close to the average for the region (Table 1). Rainfall was above average in May, with over one-half occurring during the third week in May, but slightly below the long-term average for the region for the remainder of the season. The 1997 season was characterized by cool and dry conditions until mid-June followed by a wet and warm July and a dry and warm August and September. Irrigation water totaling $320 \mathrm{~mm}$ in 1996 and $269 \mathrm{~mm}$ in 1997 was applied to supplement the rainfall. Based on water balance calculations, there were two major leaching events ( $>5 \mathrm{~cm}$ water within a 48 -h period) in 1996 occurring at about 20 and $50 \mathrm{~d}$ after emergence, and three major leaching events in 1997 occurring at $\approx 40,50$, and $75 \mathrm{~d}$ after emergence.

Tuber yield. Total tuber yield, averaged across $\mathrm{N}$ sources and rates, was significantly higher in 1996, probably because of cooler growing conditions and poor tuber set in 1997 (Table 2). Total yield was $3.9 \mathrm{Mg} \cdot \mathrm{ha}^{-1}$ greater with POCU than with urea. Similar effects of cropping year and $\mathrm{N}$ source were observed for marketable yield (i.e., yield of tubers $>85 \mathrm{~g}$ minus culls) and yield of tubers in the 170-340-g and >340-g size grades. The percentage of marketable yield that graded into the $>170$-g category was similar for both $\mathrm{N}$ sources in $1996($ mean $=62.6 \%)$ but significantly higher with POCU (73.4\%) than with urea $(68.3 \%)$ in 1997 . This yield category is important because premiums are awarded or penalties imposed depending on the percentage of the marketable yield that falls in the $>170$-g category, as discussed in the economic analysis below.

Yield results obtained in this study suggest better $\mathrm{N}$ use efficiency with POCU than with urea. This, in turn, could reduce loss of $\mathrm{N}$ through leaching.

Trend analysis of the data revealed significant linear relationships between rate of $\mathrm{N}$

Table 1. Mean monthly rainfall and air temperature data for the 1996 and 1997 growing seasons and the 30year mean at Becker, Minn.

\begin{tabular}{|c|c|c|c|c|c|c|}
\hline \multirow[b]{2}{*}{ Month } & \multicolumn{3}{|c|}{ Rainfall } & \multicolumn{3}{|c|}{ Temp } \\
\hline & 1996 & 1997 & $\begin{array}{c}\text { 30-year } \\
\text { mean }^{2}\end{array}$ & 1996 & 1997 & $\begin{array}{l}\text { 30-year } \\
\text { mean }^{2}\end{array}$ \\
\hline & --- & $-\mathrm{mm}$ & ---- & --- & $-{ }^{\circ} \mathrm{C}$ & ---1 \\
\hline April & 32 & 13 & 61 & 4.2 & 5.6 & 6.4 \\
\hline May & 106 & 43 & 87 & 13.4 & 11.0 & 13.3 \\
\hline June & 82 & 62 & 115 & 20.8 & 21.3 & 18.2 \\
\hline July & 101 & 245 & 98 & 20.5 & 22.2 & 21.2 \\
\hline August & 62 & 113 & 102 & 21.6 & 20.1 & 19.5 \\
\hline September & 40 & 38 & 86 & 16.3 & 17.4 & 14.1 \\
\hline
\end{tabular}

${ }^{\mathrm{z}}$ Average for the 30-year period 1961-90. application and all yield parameters except total and cull tuber yields (Table 2). Yield of undersized $(\leq 85 \mathrm{~g})$ and medium-sized (85-170 g) tubers decreased $8.47\left(r^{2}=0.95, P \leq 0.01\right)$ and $2.07 \mathrm{~kg} \cdot \mathrm{ha}^{-1} \mathrm{~N}\left(r^{2}=0.99, P \leq 0.01\right)$, respectively, whereas yield of large $(170-340 \mathrm{~g})$ and jumbo $(>340 \mathrm{~g})$ tubers increased $1.02\left(r^{2}=\right.$ $0.68, P \leq 0.1)$ and $2.27 \mathrm{~kg} \cdot \mathrm{ha}^{-1} \mathrm{~N}\left(r^{2}=0.85, P \leq\right.$ 0.05 ), respectively, as additional $\mathrm{N}$ rate increased from 110 to $290 \mathrm{~kg} \cdot \mathrm{ha}^{-1}$ (Table 3). However, the linear trend differed between years $(P \leq 0.01)$ for marketable tubers larger than $170 \mathrm{~g}$ (Table 3). In 1996, yield in this category increased $0.076 \% / \mathrm{kg} \mathrm{N}$, whereas the increase was $0.029 \% / \mathrm{kg} \mathrm{N}$ in 1997 . In both years, these yield increases were significant at $P=0.01$.

These results corroborate earlier reports that positive $\mathrm{N}$ responses usually involve higher rates of $\mathrm{N}$ application increasing the proportion of total yield in the large size categories while reducing that in the small size grades (Moorby, 1967; Waterer, 1997). The quadratic component of response to rate of $\mathrm{N}$ as either urea or POCU was not significant for any of the yield parameters.

Note that although the total yield was lower in 1997, the percentage of the yield in the $>170$-g size grade was higher than that obtained in 1996, suggesting that tuber set, which was not measured in this study, may have been poor in 1997. This is consistent with reports cited by Vos (1999), which indicate that mean tuber size is inversely related to the number of tubers set per plant.

Our yield results differ from the negative responses reported with SCU, nitroform, and IBDU in previous studies (Elkashif et al., 1983; Lorenz et al., 1972, 1974). Several reasons may be offered for this difference. First, POCU used in the current study was designed to release $\mathrm{N}$ at a faster rate than $\mathrm{SCU}$, nitroform, and IBDU. Second, a small amount of soluble $\mathrm{N}\left(30 \mathrm{~kg} \cdot \mathrm{ha}^{-1}\right)$ was used in all treatments in this study to ensure adequate early growth. Third, Lorenz et al. $(1972,1974)$ used a 100-d cultivar, compared with the 120-130-d cultivar used in the current study, which allowed a longer period for $\mathrm{N}$ release and subsequent uptake by the crop. Finally, the soil in this study had a coarser texture and was therefore more susceptible to leaching losses, giving the CRF an advantage over the more leachable soluble form. In another study, Liegel and Walsh (1976) reported better yields with SCU than with urea only when leaching prevailed during part of the growing season. 
Table 2. Effect of source and rate of $\mathrm{N}$ application on 'Russet Burbank' potato tuber grade, yield, and quality.

\begin{tabular}{|c|c|c|c|c|c|c|c|c|c|c|}
\hline \multirow[b]{2}{*}{ Variable } & \multicolumn{5}{|c|}{ Tuber grade $(\mathrm{g})$} & \multirow{2}{*}{$\begin{array}{c}\text { Total } \\
\text { yield }\end{array}$} & \multirow{2}{*}{$\begin{array}{c}\text { Marketable } \\
\text { yield }\end{array}$} & \multirow[b]{2}{*}{$>170 \mathrm{~g}^{2}$} & \multirow{2}{*}{$\begin{array}{l}\text { Specific } \\
\text { gravity }\end{array}$} & \multirow{2}{*}{$\begin{array}{c}\text { Hollow } \\
\text { heart }\end{array}$} \\
\hline & Culls & $<85$ & $85-1700$ & $170-340$ & $>340$ & & & & & \\
\hline Year & --- & --- & ----1 & - Mg.ha & --- & --- & ----- & $\%$ & & $\%$ \\
\hline 1996 & 2.2 & 7.8 & 19.4 & 24.3 & 8.7 & 62.4 & 52.4 & 62.6 & 1.0911 & 22.9 \\
\hline 1997 & 2.9 & 5.1 & 11.8 & 18.6 & 10.3 & 48.8 & 40.7 & 70.8 & 1.0877 & 15.8 \\
\hline \multicolumn{11}{|l|}{$\mathrm{N}$ source } \\
\hline Urea $^{y}$ & 2.2 & 6.5 & 15.7 & 20.9 & 8.3 & 53.6 & 44.9 & 65.3 & 1.0893 & 20.2 \\
\hline $\mathrm{POCU}^{\mathrm{x}}$ & 2.9 & 6.4 & 15.6 & 22.0 & 10.6 & 57.5 & 48.2 & 68.1 & 1.0895 & 18.5 \\
\hline \multicolumn{11}{|l|}{$\mathrm{N}$ rate $\left(\mathrm{kg} \cdot \mathrm{ha}^{-1}\right)$} \\
\hline 110 & 2.3 & 7.2 & 17.6 & 20.6 & 7.2 & 55.0 & 45.4 & 61.8 & 1.0900 & 16.0 \\
\hline 155 & 2.7 & 6.9 & 16.5 & 20.6 & 8.2 & 54.9 & 45.2 & 63.8 & 1.0888 & 20.0 \\
\hline 200 & 2.3 & 6.2 & 15.4 & 22.2 & 10.7 & 56.7 & 48.2 & 68.2 & 1.0899 & 20.3 \\
\hline 245 & 2.6 & 6.1 & 14.8 & 21.4 & 10.0 & 54.9 & 46.2 & 68.5 & 1.0889 & 19.2 \\
\hline 290 & 2.9 & 5.8 & 13.8 & 22.5 & 11.4 & 56.4 & 47.8 & 71.4 & 1.0891 & 21.1 \\
\hline $\begin{array}{l}\text { ANUVA } \\
\text { Year (Yr) }\end{array}$ & 0.28 & $<0.01$ & $<0.01$ & $<0.01$ & 0.09 & \multicolumn{2}{|c|}{$P>\mathrm{F}$} & 0.01 & 0.04 & 0.08 \\
\hline Source (So) & $<0.01$ & 0.85 & 0.90 & 0.05 & $<0.01$ & $<0.01$ & $<0.01$ & $<0.01$ & 0.65 & 0.42 \\
\hline Rate & 0.48 & $<0.01$ & $<0.01$ & 0.07 & $<0.01$ & 0.61 & 0.15 & $<0.01$ & 0.38 & 0.59 \\
\hline Linear & 0.23 & $<0.01$ & $<0.01$ & 0.02 & $<0.01$ & 0.40 & 0.09 & $<0.01$ & 0.32 & 0.22 \\
\hline Quadratic & 0.73 & 0.62 & 0.65 & 0.95 & 0.33 & 0.90 & 0.73 & 0.55 & 0.70 & 0.53 \\
\hline So $\times$ Rate & 0.24 & 0.22 & 0.47 & 0.44 & 0.77 & 0.61 & 0.37 & 0.58 & 0.45 & 0.52 \\
\hline Yr $\times$ So & 0.78 & 0.24 & 0.06 & 0.62 & 0.34 & 0.56 & 0.82 & 0.04 & 0.88 & $<0.01$ \\
\hline Yr $\times$ Rate & 0.42 & 0.18 & 0.11 & 0.17 & 0.10 & 0.69 & 0.50 & 0.03 & 0.89 & 0.66 \\
\hline $\mathrm{Yr} \times$ So $\times$ Rate & 0.23 & 0.13 & 0.19 & 0.48 & 0.24 & 0.62 & 0.73 & 0.10 & 0.73 & 0.39 \\
\hline
\end{tabular}

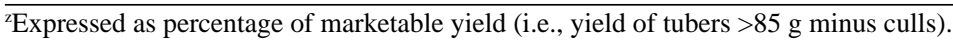

${ }^{y}$ Split equally between emergence and hilling.

${ }^{x}$ Applied in a single application at planting.

Tuber quality. Both specific gravity and internal tuber disorder, averaged across $\mathrm{N}$ sources and rates, were higher in 1996 than in 1997 (Table 2). However, year $\times$ source interaction was significant for hollow heart, with incidence of the disorder remaining the same in both years when POCU was applied, while it decreased from $28 \%$ in 1996 to $13 \%$ in 1997 with urea application. This interaction is not easily explained. Hollow heart and specific gravity were not affected by $\mathrm{N}$ rate (Table 2 ).

Since 'Russet Burbank' potatoes in the upper Midwest are grown primarily for processing, high specific gravity is desirable. In the present study, specific gravity averaged 1.0911 in 1996 and 1.0877 in 1997, and was within the range (1.071 to 1.090$)$ considered normal for most types of potatoes (Curwen et al., 1982; Martin et al., 1993).

Economic considerations. For economic analysis, the price of marketable potato tubers was assumed to be $\$ 0.10 / \mathrm{kg}$. The price of urea was set at $\$ 0.55 / \mathrm{kg} \mathrm{N}$ and that of POCU at $\$ 3.75 / \mathrm{kg}$ N (Trenkel, 1997). The application cost was assumed to be $\$ 22.00 /$ ha per application. In accordance with current standard market practice, a premium of $\$ 0.10$ per $100 \mathrm{~kg}$ was awarded for each percentage point above $60 \%$ with respect to yield of tubers larger than $200 \mathrm{~g}$ (percentage of marketable yield). Conversely, a penalty of $\$ 0.11$ per $100 \mathrm{~kg}$ was imposed for each percentage point below $55 \%$. Net return was calculated based on the cost of the $\mathrm{N}$ fertilizer plus its application and the gross value of the potato crop.

At equivalent $\mathrm{N}$ rate, estimated returns were higher in 1996 than in 1997 (Table 4). Gross return, averaged across years and rates, was $10 \%$ higher with POCU than with urea $(P \leq 0.01)$. This is consistent with marketable yield and the yield of tubers larger than $170 \mathrm{~g}$, which showed similar responses to POCU.
Gross and net return increased $\$ 5.48$ and $\$ 3.33$ / $\mathrm{kg} \mathrm{N}$, respectively, in 1996 but showed no significant response to $\mathrm{N}$ application in 1997 (Table 5). Responses (slope coefficients) of both returns to $\mathrm{N}$ rate differed for 1996 and $1997(P=0.04$ for both gross and net return), and for urea and POCU (Table 5). With urea, net return increased linearly with $\mathrm{N}$ rate $(\$ 3.13 /$ $\mathrm{kg} \mathrm{N}$ ), but there was no significant change across POCU application rates.

In the absence of regulatory limits for $\mathrm{N}$ application, soluble urea would be the source of choice because of higher net return at the higher $\mathrm{N}$ rates. However, this analysis does not take into account the environmental costs due to potentially higher $\mathrm{NO}_{3}^{-}$leaching associated with urea than with POCU. With better economic conditions, such as higher prices for potatoes or lower costs for POC fertilizers, and if government regulation sets $\mathrm{N}$ application at lower rates to reduce $\mathrm{NO}_{3}^{-}$loss, the situation might shift in favor of POC fertilizer use.

Table 3. Effect of cropping year on the linear response of 'Russet Burbank' tubers $>170$ $\mathrm{g}$ to $\mathrm{N}$ application.

\begin{tabular}{|c|c|c|}
\hline \multirow{2}{*}{$\begin{array}{l}\text { N rate } \\
\left(\mathrm{kg} \cdot \mathrm{ha}^{-1}\right)\end{array}$} & \multicolumn{2}{|c|}{ Marketable tubers $>170 \mathrm{~g}^{2}$} \\
\hline & 1996 & 1997 \\
\hline & $----\%$ & ---- \\
\hline 110 & 55.1 & 68.6 \\
\hline 155 & 58.6 & 69.0 \\
\hline 200 & 65.4 & 71.5 \\
\hline 245 & 64.7 & 71.6 \\
\hline 290 & 69.1 & 73.6 \\
\hline \multicolumn{3}{|l|}{ Regression } \\
\hline Intercept & 47.5 & 65.2 \\
\hline Slope & 0.0756 & 0.0289 \\
\hline$r^{2}$ & $0.92^{* *}$ & $0.94^{* *}$ \\
\hline
\end{tabular}

${ }^{\mathrm{z}}$ Expressed as percentage of marketable yield (i.e., yield of tubers $>85 \mathrm{~g}$ minus culls).

** Significant at $P \leq 0.01$.
Results obtained in this study corroborate recent findings on the economics of using multinutrient CRFs, including POC fertilizers, in citrus production (Obreza et al., 1999). Obreza et al. (1999) concluded that the use of CRFs alone is not economical unless it is combined with conventional fertilizer application, or the cost of coating CRFs decreases.

Table 4. Economic analysis of POCU and urea N applications for irrigated Russet Burbank potatoes.

\begin{tabular}{|c|c|c|}
\hline Variable & $\begin{array}{l}\text { Gross } \\
\text { return }\end{array}$ & $\begin{array}{c}\text { Net } \\
\text { return }\end{array}$ \\
\hline Year & --- & --1 \\
\hline 1996 & 4980 & 4500 \\
\hline 1997 & 4080 & 3610 \\
\hline \multicolumn{3}{|l|}{ N Source } \\
\hline Urea $^{y}$ & 4320 & 4150 \\
\hline POCU ${ }^{x}$ & 4740 & 3970 \\
\hline \multicolumn{3}{|l|}{ N Rate $\left(\mathrm{kg} \cdot \mathrm{ha}^{-1}\right)$} \\
\hline 110 & 4230 & 3950 \\
\hline 155 & 4290 & 3910 \\
\hline 200 & 4840 & 4380 \\
\hline 245 & 4520 & 3920 \\
\hline 290 & 4810 & 4140 \\
\hline ANOVA & --- & $P>\mathrm{F}---$ \\
\hline Year & 0.01 & 0.01 \\
\hline Source & $<0.01$ & 0.05 \\
\hline Rate & $<0.01$ & 0.11 \\
\hline Source $\times$ rate & 0.34 & 0.04 \\
\hline Year $\times$ source & 0.75 & 0.75 \\
\hline Year $\times$ rate & 0.09 & 0.09 \\
\hline Year $\times$ source $\times$ rate & 0.65 & 0.65 \\
\hline \multicolumn{3}{|l|}{ Contrasts } \\
\hline $\mathrm{N}$ rate linear & $<0.01$ & 0.21 \\
\hline $\mathrm{N}$ rate quadratic & 0.43 & 0.43 \\
\hline Source $\times$ linear $N$ & 0.55 & 0.01 \\
\hline Source $\times$ quadratic $N$ & 0.97 & 0.97 \\
\hline Year $\times$ linear $N$ & 0.01 & 0.01 \\
\hline Year $\times$ quadratic $\mathrm{N}$ & 0.77 & 0.77 \\
\hline
\end{tabular}

${ }^{\mathrm{z}}$ Net return $=$ gross return minus fertilizer $\mathrm{N}$ cost minus cost of $\mathrm{N}$ application.

${ }^{y}$ Split equally between emergence and hilling.

${ }^{\mathrm{x}}$ Applied in a single application at planting. 
Table 5. Linear response of gross and net returns from irrigated 'Russet Burbank' potatoes as affected by year and $\mathrm{N}$ source.

\begin{tabular}{|c|c|c|c|c|c|c|}
\hline \multirow{2}{*}{$\begin{array}{l}\text { N rate } \\
\left(\mathrm{kg} \cdot \mathrm{ha}^{-1}\right)\end{array}$} & \multicolumn{2}{|c|}{ Gross return } & \multicolumn{4}{|c|}{ Net return $^{2}$} \\
\hline & 1996 & 1997 & 1996 & 1997 & Urea $^{y}$ & $\mathrm{POCU}^{\mathrm{x}}$ \\
\hline & \multicolumn{5}{|c|}{$--------------\$$ /h --} & ---1 \\
\hline 110 & 4490 & 3971 & 4209 & 3690 & 3948 & 3951 \\
\hline 155 & 4576 & 3994 & 4199 & 3617 & 3729 & 4087 \\
\hline 200 & 5289 & 4321 & 4815 & 3889 & 4533 & 4099 \\
\hline 245 & 5156 & 3958 & 4532 & 3387 & 4234 & 3745 \\
\hline 290 & 5430 & 4187 & 4762 & 3520 & 4400 & 3882 \\
\hline \multicolumn{7}{|l|}{ Regression } \\
\hline Intercept & 3893 & 3904 & 3849 & 3860 & 3543 & 4166 \\
\hline Slope & 5.48 & 0.88 & 3.33 & -1.27 & 3.13 & -1.07 \\
\hline$r^{2}$ & $0.83^{*}$ & $0.17^{\text {Ns }}$ & $0.64^{++}$ & $0.30^{\text {Ns }}$ & $0.46^{++}$ & $0.26^{\mathrm{Ns}}$ \\
\hline
\end{tabular}

${ }^{2}$ Net return $=$ gross return minus fertilizer $\mathrm{N}$ cost minus cost of $\mathrm{N}$ application.

${ }^{y}$ Split equally between emergence and hilling.

${ }^{\mathrm{x}}$ Applied in a single application at planting.

ws, ++, Nonsignificant or significant at $P \leq 0.1$ or 0.05 , respectively.

\section{Literature Cited}

Alva, A.K. 1992. Differential leaching of nutrients from soluble vs. controlled-release fertilizers. Environ. Mgt. 16:769-776.

Carlson, R.M. 1990. Rapid direct determination of ammonium and nitrate in soil and plant tissue extracts. Commun. Soil Sci. Plant Anal.21:15191529.

Cox, D. and T.M. Addiscott. 1976. Sulfur coated urea as a fertilizer for potatoes. J. Sci. Food Agr. 27:1015-1020.

Curwen, D., K.A. Kelling, J.A. Schoenemann, W.R. Stevenson, and J.A. Wuman. 1982. Commercial potato production and storage. Wisconsin Agr. Expt. Sta. Bul. A2257.

Elkashif, M.E., S.J. Locascio, and D.R. Hensel. 1983. Isobutylidene diurea and sulfur-coated urea as $\mathrm{N}$ sources for potatoes. J. Amer. Soc. Hort. Sci. 108:523-526.

Errebhi, M., C.J. Rosen, and D.E. Birong. 1998a. Calibration of a petiole sap nitrate test for irrigated 'Russet Burbank' potato. Commun. Soil Sci. Plant Anal. 29:23-35.

Errebhi, M., C.J. Rosen, S.C. Gupta, and D.E. Birong. 1998b. Potato yield response and nitrate leaching as influenced by nitrogen management. Agron. J. 90:10-15.

Gandeza, A.T., S. Shoji, and I. Yamada. 1991. Simulation of crop response to polyolefin-coated urea. I. Field dissolution. Soil Sci. Soc. Amer. J. 55:1462-1467.

Hutchison, W. 1996. Commercial vegetable pest management: production guide. Minnesota Agr. Ext. Serv. Bul. 1880-S (revised). p. 67-74.

Knudsen, D., G.A. Peterson, and P.F. Pratt. 1982. Lithium, sodium, and potassium, p. 225-246.
In: A.L. Page (ed.). Methods of soil analysis Part 2. Chemical methods. Agron. Monogr. 9. ASA and SSSA, Madison, Wis.

Kuo, S. 1996. Phosphorus, p. 869-919. In D.L. Sparks, A.L. Page, P.A. Helmke, R.H. Loeppert, P.N. Soltanpour, M.A. Tabatabai, C.T. Johnson, and M.E. Sumner (eds.). Methods of soil analysis. Part 3. Chemical methods. SSSA Book Ser. 5. SSSA and ASA, Madison, WI.

Liegel, E.A. and L.M. Walsh. 1976. Evaluation of sulfur coated urea (SCU) applied to irrigated potatoes and corn. Agron. J. 68:457-463.

Lorenz, O.A., B.L. Weir, and J.C. Bishop. 1972. Effect of controlled-release nitrogen fertilizers on yield and nitrogen absorption by potatoes, cantaloupes, and tomatoes. J. Amer. Soc. Hort. Sci. 97:334-337.

Lorenz, O.A., B.L. Weir, and J.C. Bishop. 1974. Effect of sources of nitrogen on yield and nitrogen absorption of potatoes. Amer. Potato J. 51:56-65.

Martin, H.W., D.A. Graetz, S.J. Locascio, and D.R Hensel. 1993. Nitrification inhibitor influences on potato. Agron. J. 85:651-655.

Maynard, D.N. and O.A. Lorenz. 1979. Controlled release fertilizers for horticultural crops. Hort. Rev. 1:79-140.

Moorby, J. 1967. Inter-stem and inter-tuber competition in potatoes. Eur. Potato J. 10:189-205.

Nelson, D.W. and L.E. Sommers. 1996. Total carbon, organic carbon, and organic matter, p. 9611010. In: D.L. Sparks, A.L. Page, P.A. Helmke, R.H.Loeppert, P.N. Soltanpour,M.A. Tabatabai, C.T. Johnson, and M.E. Sumner (eds.). Methods of soil analysis. Part 3. Chemical methods. SSSA Book Ser. 5. SSSA and ASA, Madison, Wis. Obreza, T.A., R.E. Rouse, and J.B. Sherrod. 1999.
Economics of controlled-release fertilizer use on young citrus trees. J. Prod. Agr. 12:69-73.

Rosen, C.J., D. Birong, and M. Zumwinkle. 1992. Nitrogen fertilization studies on irrigated potatoes: Nitrogen use, soil nitrate movement, and petiole sap nitrate analysis for predicting nitrogen needs, p. 27-47. In: Field research in soil science (Soil Series \#134). Misc. Pub. 75. Minnesota Agr. Expt. Sta., Univ. of Minnesota.

Rosen, C.J. and R. Eliason. 1996. Nutrient management for commercial fruit and vegetable crops in Minnesota. Minnesota Ext. Serv. Bul. BU-5886E

Rosen, C.J., M. Errebhi, J. Moncrief, S. Gupta, H.H Cheng, and D. Birong. 1993. Nitrogen fertilization studies on irrigated potatoes: Nitrogen use, soil nitrate movement, and petiole sap nitrate analysis for predicting nitrogen needs $-1992, \mathrm{p}$. 14-33. In: Field research in soil science (Soil Series \#136). Misc. Pub. 79. Minnesota Agr. Expt. Sta.

SAS Institute. 1990. SAS/STAT user's guide, vers. 6.04. SAS Inst., Cary, N.C.

Shoji, S. and A.T. Gandeza. 1992. Controlled-release fertilizers with polyolefin resin coating: Development, properties, and utilization. Konno Printing Co., Ltd., Sendai, Japan.

Shoji, S., A.T. Gandeza, and K. Kimura. 1991. Simulation of crop response to polyolefin-coated urea. II. Nitrogen uptake by corn. Soil Sci. Soc. Amer. J. 55:1468-1473.

Thomas, G. W. 1996. Soil pH and soil acidity, p. 475-490. In: D.L. Sparks, A.L. Page, P.A. Helmke, R.H. Loeppert, P.N. Soltanpour, M.A Tabatabai,C.T. Johnson, and M.E. Sumner(eds.). Methods of soil analysis. Part 3. Chemical methods. SSSA Book Ser. 5. SSSA and ASA, Madison, Wis.

Trenkel, M.E. 1997. Improving fertilizer use efficiency: Controlled-release and stabilized fertilizers in agriculture. Intl. Fert. Ind. Assn., Paris.

Vos, J. 1999. Potato, p. 333-354. In: D.L. Smith and C. Hamel (eds.). Crop yield, physiology, and processes. Springer-Verlag, Berlin, Heidelberg.

Waddell, J.T., S.C. Gupta, J.F. Moncrief, C.J. Rosen, and D.D. Steele. 1999. Irrigation and nitrogen management effects on potato yield, tuber quality, and nitrogen uptake. Agron. J. 91:991-997.

Wang, F.L. and A.K. Alva. 1996. Leaching of nitrogen from slow-release urea sources in sandy soils. Soil Sci. Soc. Amer. J. 60:1454-1458.

Waterer, D. 1997. Influence of irrigation, nitrogen, and seed piece spacing on yields and tuber size distribution of seed potatoes. Can. J. Plant Sci. 77:141-148.

Wright, J. and F. Bergsrud. 1991. Irrigation scheduling: Checkbook method. Minnesota Ext. Serv. AG-FO-1322-C. 